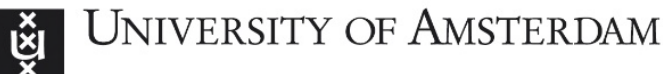

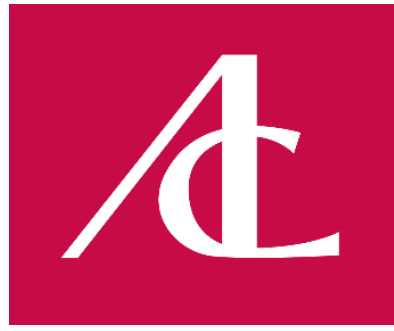

Amsterdam

Center for

International

Law

\title{
IUS GENTIUM ET NATURALE: THE HUMAN CONSCIENCE AND EARLY MODERN INTERNATIONAL LAW
}

Janne E. Nijman

Amsterdam Law School Legal Studies Research Paper No. 2020-63

Amsterdam Center for International Law No. 2020-32

ASSER Research Paper 2020-14 


\section{Research paper series}

\section{ASSER INSTITUTE}

Centre for International \& European Law

3 December 2020

IUS GENTIUM ET NATURAE:

THE HUMAN CONSCIENCE AND EARLY

MODERN INTERNATIONAL LAW

Janne E. Nijman
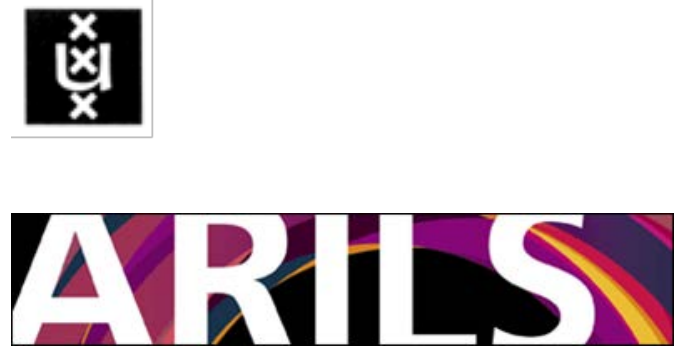
This text may be downloaded for personal research purposes only. Any additional reproduction for other purposes, whether in hard copy or electronically, requires the consent of the author. If cited or quoted, reference should be made to the full name of the author, the title, the working paper or other series, the year, and the publisher.

(C) Janne E. Nijman, 2020

Forthcoming in: Slotte, P. \& Haskell, J. (Eds.), Christianity and International Law: An Introduction (Cambridge Law and Christianity), Cambridge University Press (2021)

Link to SSRN Asser page

www.asser.nl

Cite as: ASSER Research Paper 2020-14

Amsterdam Law School Research Paper No. 2020-63

Amsterdam Center for International Law No. 2020-32

Author Contact Details: j.nijman@asser.nl or J.E.Nijman@uva.nl 


\section{Abstract}

This chapter is an intellectual history of ius gentium et naturae for a volume on the relations between international law and Christianities. It examines how various early modern conceptions of conscientia relate to the emergence of ius gentium et naturae in the so-called Age of Conscience. It zooms in on the development of 'modern' ius gentium et naturae amidst the early modern fight over the human conscience, in particular through the work of Hugo Grotius.

To start, it introduces the Thomist conception of conscience as 'forum internum', which is able to err and thus needs the Church to provide direct guidance and correction. Subsequently, it analyses the role played by this judicial conception of conscience in the work of Spanish Scholastic Francisco de Vitoria when he reconceives ius gentium et naturae as a body of law applicable to Christian and non-Christian peoples. Ius gentium et naturae is thus born within the Roman Catholic tradition and entangled in the institution of confession or in 'the power of the pastorate' as Michiel Foucault would coin it. Subsequently, the chapter examines briefly how the Reformations spurred a revisit of the relation between conscience and reason, in the sense of natural law. Tables were turned and reason, or natural law, was argued to be inferior to conscience and faith. The core of of the chapter is a discussion of how Grotius' conception of the human conscience, which drew on both Thomism and Erasmian humanism, in turn led to a ius gentium et naturae disentangled from Roman Catholic moral theology, doctrine, and practice. For Grotius reason and conscience underpinned a universal law of nature, backed up by a decentralised - internal - court system ('forum internum' or 'forum conscientia'), which was equally operated by Christian, Catholic and Protestant, Gewissener and non-Christian sovereigns and peoples alike.

Today, 'conscience' is uncritically assumed, or used explicitly, in international law (eg in the 1998 Rome Statute or the 1948 Universal Declaration of Human Rights) as a natural place of morality and justice. With the human conscience explictly or implicitly underpinning international law comes however a space for politics. As we have seen time and again, while human conscience is the space for humans to apply moral knowledge, it is also the space to err profoundly. Law presupposes its application by the human conscience, and without the latter the very existence of the former becomes unimaginable. The politics that come with the interpretations of the court of conscience, like with any court, requires our unwaning scrutinizing attention.

\section{Keywords}

ius gentium, scholasticism, humanism, natural law, forum internum, conscientia, reason, Erasmus, Foucault, Grotius, Vitoria 


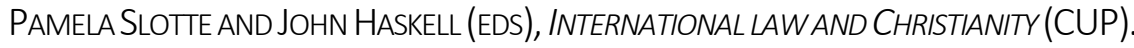

\section{CHAPTER 22}

\section{IUS GENTIUM ET NATURAE:}

\section{THE HUMAN CONSCIENCE AND EARLY MODERN INTERNATIONAL LAW}

Janne E. Nijman

\section{INTRODUCTION}

What to focus on in an intellectual history of ius gentium et naturae for a volume on the relations between international law and Christianities? For centuries, (international) law and Christian theology maintained intensive and complex relations which it is impossible to do justice to within the scope of this chapter. ${ }^{1}$ With the more recent 'turn to history' in international legal scholarship, discussions of the relationship between ius gentium et naturae and Christianity generally centre on secularisation and/or empire. ${ }^{2}$ For obvious reasons both sets of histories deal with early modernity - the time that the so-called Respublica Christiana or Holy Roman Empire was profoundly affected by Reformations, gradually fragmented, and religious and theological fights were part of the politics of the newly emerging European nation-states. ${ }^{3}$ These states started to maintain relations, wage (religious) wars, compete over overseas trade and occupation, and engage in violent relations with peoples in Africa, Asia and the Americas. Both sets of histories build on the idea that early modern European scholars were looking for a solid and common basis for universal law applicable to relations among sovereigns and peoples from different Christian denominations as well as among Christian and non-Christian sovereigns and peoples. Since international law became defined by (the model of) the 'modern state' as developed in Christian Europe, international law's historical narratives have been overwhelmingly Eurocentric. ${ }^{4}$ Since this chapter aims to contribute a history of ius gentium et naturae in the context of international law and Christianities, it cannot escape the focus on early modern Europe either.

In early modernity, the influence of Christianities on the development of (international) law revolved around the concepts of reason and conscience. Christian natural law theory dominated this (trans)formative era of ius gentium et naturae: it was a deeply Christian Europe that rediscovered ancient Roman law (a ratio scripta) in the eleventh-century. The conceptions of ius gentium et naturae which developed in medieval jurisprudence, both civil and canon, were pervaded with Christian theology. ${ }^{5}$ Both legal systems, individually and

\footnotetext{
${ }^{1}$ Cf M Koskenniemi et al (eds), International Law and Religion (Oxford: OUP 2017).

${ }^{2}$ Cf M Koskenniemi et al (eds), International law and Empire (Oxford: OUP 2017).

${ }^{3} \mathrm{Cf}$ S Mortimer, 'Law, Justice, and Charity' in Koskenniemi et al (Eds), International Law and Religion (n 1). Also, R Tuck, The Rights of War and Peace (Oxford: OUP 1999) 28.

${ }^{4}$ See M Koskenniemi, Histories of International law: Dealing with Eurocentrism (2011). A Becker Llorca, Eurocentrism in the history of international law, Oxford Handbook History of International Law (OUP 2012), 1034.

${ }^{5}$ W Decock, Theologians and Contract Law. The Moral Transformation of the lus Commune (ca 1500-1650) (Martinus Nijhoff Publishers: 2013); R Lesaffer 'Roman Law and the Intellectual History of International Law in: Hoffmann and Orford (Eds) The Oxford Handbook of the Theory of International Law (OUP: 2016) 50.
} 
conjoined as ius commune, were applied and enforced by secular and ecclesiastical courts (forum externum). Reason and human conscience became foundational to moral and legal thought and legal reform: '[i]t was generally believed that human law derived ultimately from, and was to be tested by, reason and conscience. ${ }^{6}$ Roman Catholic doctrine of reason and conscience gave way to the medieval conception of (all) law. In the twelfth century 'the canonists and Romanists of western Europe deepened the earlier concepts of reason and equity by adding to them the Judaic and Christian concept of conscience, which they related to mercy and love. ${ }^{7}$

During the Middle Ages, reason and conscience were obvious moral and legal philosophical notions without which law and justice in this world (and 'hereafter') were simply impossible. Together reason and conscience were reforming custom (a predominant source of law) and constitutive of the Christianised Graeco-Roman conception of equity as justice. ${ }^{8}$ Conscience of humans and communitities had to give prevalence to the (Christian) moral principles of natural law at all times. The Protestant Reformations turned against the Roman Catholic Church's rule of conscience. Sixteenth and seventeenth-century theological, legal and political philosophical debates often came to centre on the human conscience and its relationship with reason, law and God.

'The seventeenth century can justly be called the Age of Conscience. [...] For much of the century it was generally believed that conscience, not force of habit or self-interest, was what held together the social and political order. ${ }^{9}$

The present chapter zooms in on the development of 'modern' ius gentium et naturae amidst this fight over the human conscience and examines how conceptions of human conscience underpinned early modern ius gentium et naturae thinking, in particular through the work of Hugo Grotius. The next section first introduces the Thomist conception of conscience as 'forum internum', which is free to err and thus needs the Church's provides direct guidance and correction. Subsequently, we analyse the role this judicial conception of conscience plays in the work of Spanish Scholastic Francisco de Vitoria when he reconceives ius gentium et naturae into a body of law applicable to Christian and non-Christian peoples. Ius gentium et naturae is thus born within the Roman Catholic tradition and entangled in the institution of confession or in 'the power of the pastorate' as Michiel Foucault coined it. Section 3 then start with examining briefly how the Reformations spurred a revisit of the relation between conscience and reason, in the sense of natural law. Tables were turned and reason or natural law was argued to be inferior to conscience and faith. The core of section 3 discusses however how Grotius' conception of the human conscience, which drew on both Thomism and Erasmian humanism, led to a ius gentium et naturae disentangled from Roman Catholic moral theology, doctrine, and practice. Reason and conscience underpinned a universal law of nature backed up by a decentralised - internal - court system, which was equally operated by Christian, Catholic and Protestant, Gewissener and non-Christian sovereigns and peoples alike. Section 4 will conclude this chapter.

\footnotetext{
${ }^{6} \mathrm{H}$ Berman, Law and Revolution I (HUP, 1983), at 12.

${ }^{7}$ Berman (n 6) at 146, 196: 'mercy asserted itself as a principle under the Graeco-Roman name of aequitas ("equity")', 253, 518-519.

${ }^{8}$ Berman (n 6), at 11-12, 111

${ }^{9}$ Keith Thomas, 'Cases of Conscience in Seventeenth-Century England' in Morrill, John; Slack, Paul and Woolf, Daniel (eds), Public duty and private conscience in seventeenth-century England. Essays presented to G.E. Ay/mer (Clarendon Press 1993), at 29.
} 


\section{HUMAN CONSCIENCE IN SPANISH SCHOLASTICS}

In the early sixteenth century, moral theologians reworked the concept of ius gentium et naturae mostly by engaging with Thomas Aquinas' (c 1225-1274) work. Reason and conscience were crucial to this move. In early modern Christian theology and jurisprudence, conceptions of conscience were at the heart of heated debates on free will, predestination, salvation, redemption, and ultimately on the moral quality of the human soul after the Fall from Grace. A full history of the concept of conscience is outside the purpose and scope of this chapter. Here it suffices to point out that the concept of 'conscience' was subject to (doctrinal) discussions in Christian theology ever since the writings of Church Fathers such as Jerome, Chrysostom, and Augustine, and subsequently was a key concept in the writings of those medieval philosophers who engaged with patristic literture. Yet, only with scholastic theologian Peter Lombard (c. 1095-1160) the human conscience became a 'standard topic of later medieval philosophy.' ${ }^{10}$ Here, I pick up the discussion with Thomas Aquinas' conception of conscience as a 'court'. This section briefly discusses the 'court of conscience' conception in Aquinas, Vitoria and Suarez, and the politics that came with it, to then turn to Grotius in the remainder of this chapter.

\subsection{Thomist conception of forum conscientiae presided over by the Church}

Medieval scholastic theology discussed human conscience (conscientia) in relation to synderesis (the innate principle of reason, which directs her to do good and avoid evil). ${ }^{11}$ In the Summa theologiae, Aquinas occasionally replaces the word synderesis by the term understanding (intellectus), the intellectual virtue of grasping the first principles of natural law. ${ }^{12}$ Aquinas conceived of conscientia as the act of applying this moral knowledge to a specific case (ex ante and ex post), for which 'one can take counsel'. ${ }^{13}$ He distinguished between forum conscientiae or internum, the domain of confession and penance, and forum externum, the ecclesiastical and secular courts. The forum conscientiae was to apply moral knowledge also when it interacted with the human legal sphere. In Summa Theologiae I-II q. 96 art. 4 Aquinas asks 'whether human law binds a man in the court of conscience?' ${ }^{14}$ Here, we also find the famous adagium 'lex injusta non est lex'. Human law is binding in the 'court of conscience' provided that the human conscience does not judge it unjust. That is, unjust because it is not 'directed to the common good' or because 'it inflicts unjust harm on its subjects' (the evil that needs to be avoided). One 'is not obliged to obey the law in [the latter] cases, if [one] can resist [resistere] doing so without scandal or worse harm. ${ }^{15}$ Human obedience to authority and law is not unlimited, it involves individual moral judgment.

Aquinas distinguished sharply between temporal and spiritual power, between imperial and papal jurisdiction. Within the confrontation between these powers, Pia Valenzuela argues, Aristotelian conceptions of ius gentium served Aquinas to reject the papal theocratic theory of government argued by thirteenth century canonists. ${ }^{16}$ His conception of ius gentium as human law emanating from - yet not the same as - natural law supported the legitimacy of

\footnotetext{
${ }^{10}$ T.C. Potts, Conscience in Medieval Philosophy (CUP 1980) 1-2, 5 et seq.

${ }^{11}$ Potts (n 10) 10-11.

12 T Hoffmann 'Conscience and Synderesis', in Brian Davies (Ed), The Oxford Handbook of Aquinas (OUP 2012) 255.

${ }^{13}$ Hoffmann (n 12) 257; Aquinas, Debated Questions on Truth (De Veritate) 16-17 in Potts (n 10) 130-136, at 132.

${ }^{14}$ R W Dyson (Ed) Aquinas Political Writings (Cambridge: CUP 2002) 143-45.

${ }^{15}$ Aquinas Political Writings (14), I-II Qu. 96 'On the power of human law', pp 137-145.

${ }^{16}$ Pia Valenzuela, 'Between Scylla and Charybdis', in Koskenniemi (n 1) 12
} 
the authority and autonomy of temporal or secular government and the declericalization of legal institutions. Secular government he argued was instituted by ius gentium. ${ }^{17}$

The spiritual jurisdiction of the Church of Rome remained undisputed. Moral theologians as the Church's experts gave authoritative interpretations of natural law applicable in the 'court of conscience'. They educated the clergy on giving guidance to prevent erring of conscience and to relief the erroneous conscience by the sacrement of confession and penance. Hence, the famous "cases of conscience" 18 literature developed by this practice and in turn used to equip the future clergy in their function of confessors. In that role they were the judges of the 'court of conscience', the superior in moral judgement. A 'culture of counsel of conscience' emerged, ${ }^{19}$ the individual moral agent examined her conscience in confession to then be guided or judged and unburdened by the confessor and the sacrement of penance. The conscience was thus both free and bound. It was free in its judgement, yet bound by natural law and justice interpreted and applied authoritatively by the Church.

\subsection{Spanish scholastics: moral theologian Francisco de Vitoria (c 1480-1546)}

For sixteenth century Roman Catholic Scholastics, the conscience was the dominion of God, and the Church provided the judges to exercise jurisdiction in the 'court of conscience' and judge whether general natural law principles were applied correctly in a specific case. The moral theologians of the School of Salamanca, so significant and prominent in the history of international law, continued in the Aristotelian-Thomistic tradition well through the European Reformations. Francisco de Vitoria belonged to the Dominican Order, which was founded in Bologna in 1216 and from there led a revival of Thomas Aquinas' moral theology. He was one of the most prominent moral theologians of his time. In his classroom in Salamanca, Vitoria taught the future pastors of the Spanish Crown and Royals, the Royal ministers and advisors, Conquisatores, financiers and merchants, and soldiers, among many others, some of whom would also travel to the Americas themselves.

This is the context of what we have come to know as The First Relectio On the Indians Lately Discovered, which Vitoria gave around $1537-39 .{ }^{20} \mathrm{He}$ did not hide his task nor his troubles: ${ }^{21}$ there was no peace of mind - 'sovereigns and their advisors could not attain security and certitude of conscience' - regarding the title of Spanish rule in the Americas. ${ }^{22}$ In the opening part of this Relectio, Vitoria cited from Deuteronomy where the Levitian priests are the experts, the judges, who provide authoritative opinions binding in conscience. ${ }^{23}$ Similarly, he argued that whenever in doubt about an action being good or bad, the contemporary experts, 'those whom the Church has appointed for that purpose', had to be consulted in and out of confession. ${ }^{24}$

\footnotetext{
17 Ibidem 51.

${ }^{18}$ Grotius refers to this body of literature in both Mare Liberum and DIBP (Prolegomena).

${ }^{19} \mathrm{~N}$ Reinhardt, 'How individual was conscience in the early-modern period? Observations on the development of Catholic moral theology', 45(3) Religion 2015, 409-428.

${ }^{20} \mathrm{~F}$ de Vitoria, De Indis et De jure belli relectiones, in Ernest Nys (Ed) 'The Classics of International Law' series published by the Carnegie Institute of Washington DC, 1917, at 115-162.

${ }^{21}$ Privately, in a letter to Miguel de Arcos of 8 November 1534, Vitoria wrote: 'no business shocks me or embarrasses me more than the corrupt profits and affairs of the Indies.'

22 Vitoria (n 20) 116 and 119.

${ }^{23}$ Vitoria (n 20) 118.

${ }^{24}$ Vitoria (n 20) 118.
} 
In a preliminary argument, Vitoria argued that in any controversial matter there existed a 'duty to consult' the Church's experts and to follow their interpretation of natural law and judgment, which then would provide security in conscience. The conscience of the flock might be mistaken; hence, there was a duty 'to follow th[e] [experts'] opinion' in order to avoid $\sin .^{25}$

'For in those matters which belong to his salvation a man is bound to yield credence to the teachers appointed by the Church, and in a doubtful matter their ruling is law. For just as in the contentious forum the judge is bound to judge in accordance with what is alleged and proved, so in the forum of conscience a man is bound to base his judgment, not on his own sentiments, but on demonstrable reason or on the authority of the wise; else his judgment is presumptuous and exposes him to the risk of going wrong, and indeed he does err in the very fact. ${ }^{26}$

The rest is history, told by many. ${ }^{27}$ Victoria examined divine, natural and human law whereas all law, including civil laws, 'bind in the forum of conscience, as St. Thomas teaches (Prima Secundae, qu. 96, art. 4).'28 Ultimately, he have his opinion: there were no legitimate titles in divine law, yet he developed and interpreted natural law and applied it to the case at hand. He recalled Gaius' definition of ius gentium, that is, what natural reason has established among all nations, and redefined it as ius gentium et naturae applicable to relations between all sovereigns and peoples, Christian and non-Christian. ${ }^{29}$ Through this authoritative interpretation of the law of nature and nations, he gave birth to early modern ius gentium et naturae.

The Thomist conception of concience as forum conscientiae presided over by a confessorjudge outside the human person and ruled by natural law authoritatively developed and interpreted by the Church, allowed Vitoria to provide peace of mind to merchant and conquistador, King and soldier, involved in the Spanish conquest of the Americas.

Later on, with Francisco Suarez (1548-1617), such juridification of the human conscience persisted. He contributed to the confessional literature. Handbooks for confessors -the aforementioned "cases of conscience"- became legal treatises in this Catholic tradition. The human conscience or rational soul was subject of natural law and the confessor was to judge within the 'court of conscience' whether conscience correctly applied natural law. If erred, the Church's sacrements assist the flock in relieving the soul and saving it for 'eternal life'. Suarez too was interested in the potential of the conscience for universal law and cites from

\footnotetext{
${ }^{25}$ Vitoria (n 20) 119

${ }^{26}$ Vitoria (n 20) 117-18.

27 See eg Antony Anghie, 'Francisco De Vitoria and the Colonial Origins of International Law', 5 Soc. \& Legal Stud. (1996) 321-336; M Koskenniemi 'Vitoria and Us' 22 Rechtsgeschichte (2014) 119-138.

${ }^{28}$ Vitoria (n 20) 124; see for Vitoria teaching on Aquinas' Summa Theologia I.II. Qu 96.4 'what obliges in the court of conscience' as part of his lectures 'On Laws' in Pagden\&Lawrance (Eds), Vitoria Political Writings (Cambridge: CUP 1991) 173-179.

${ }^{29}$ Vitoria (n 20) 151. In line with the Thomist tradition, for Vitoria natural law knowledge and the faculty to apply it were at work in European as well as non-European peoples since all human beings were in imagine Deiwhether they realised it or not. Vitoria teaching on ST I-II Qu 94 in Pagden\&Lawrence 'On Laws' (n 28) 171.
} 
Paul's letter to the Romans: 'The Gentiles, who have not the law, do by nature those things that are of the law [... ], their conscience bearing witness to them.' ${ }^{30}$

\subsection{Human conscience and confession as a 'technology of the self'}

Michel Foucault has done brilliant work on the sacrements of confession and penance. In a number of Lectures at the Collège de France, he examined the Christian institution of the pastorate and the spiritual direction - 'direction de conscience' - enforced by the Church of Rome through these sacrements. ${ }^{31}$ Vast was the power that came with the complex, mutually dependent spiritual relation between pastor and flock. ${ }^{32}$ While Foucault did not deal with Vitoria specifically, the lectures of Salamanca's star-theologian testify to pastoral authority to 'prescrib[e] the law', 'teac[h] the truth', and to give way to the salvation of the individual's soul, and as such to what we would call "expert governance" operated on the human conscience. Foucault unravelled how this Christian examination of conscience, and thus of human action evaluated or anticipated in confession, created a 'new form of power'. ${ }^{33}$

In Technologies of the Self, Foucault discusses the obligatory practice of confession and penance extensively in the context of what he called 'technologies' through which humans produce knowledge (and power/domination). ${ }^{34}$ Confession and penance were the practices that reinforced the Christian pastorate and the expert rule by the institutions of the Church of Rome. Through these practices, Foucault argued, the Church was involved in 'governmentalbility' and produced domination. The practice of confession became one of the issues at stake during the Reformations and a decisive step in the move from medieval to modern legal and political thought.

\section{HUMAN CONSCIENCE IN GROTIUS' IUS GENTIUM ET NATURAE}

\subsection{Protestant Reformations and Christian humanism : Luther and Calvin - Seneca and Erasmus}

Protestant reformers such as Martin Luther (1483-1546) and Jean Calvin (1509-1564) turned ardently against involvement of clerical intermediaries in the self-examination of the human soul and against the (abuse of) power and domination that came with the law and institutions governing human conscience. ${ }^{35}$ Luther famously burned the manual for confessors, Summa Angelica (1486), in 1520 in Wittenberg. He argued 'consciences are bound by the law of God alone', not by the interpretations of natural law given by the clergy ('what is written in

\footnotetext{
${ }^{30}$ Francisco Suarez, Selections from Three Works of Francisco Suarez (Oxford: Clarendon Press; London: Humphrey Milford., 1944) Book II: On the Eternal Law, the Natural Law, and the lus Gentium: Chapter IX 'Is the Natural Law Binding in Conscience', at 223-24.

${ }^{31}$ M Foucault, Security, Territrory, Population. Lectures at the Collège de France 1977-1978, ed. by Michel Senellart (Palgrave 2009), 163 et seq; also, M Foucault, Abnormal. Lectures at the Collège de France 1974-1975 (Verso 2016), lecture Seven 19 February 1975.

32 Foucault 1977-1978 (31), 169-177.

33 Ibidem. See also Reut Yael Paz in: Hoffmann and Orford (Eds) The Oxford Handbook of the Theory of International Law (OUP: 2016) 923.

${ }^{34}$ M Foucault, Technologies of the Self: A Seminar with Michel Foucault, in: Martin, L.H. et al (London: Tavistock, 1988), 16-49, at 18 .

${ }^{35}$ Cf DeCock (n 5) 46: on how ius commune was diffused into the smallest arteries of societies by confessional practice.
} 
Scriptures is plain to all'). ${ }^{36}$ Postlapsarian human nature had to be guided by God's law and grace otherwise no good could emanate from humans. ${ }^{37}$ This affected the relation between reason and conscience: God was the highest authority for the free conscience. Conscience reconceived as 'will and intent' then employed reason. The politics of this conception of Christian conscience lies in the 'sanctity' it gave to property and contract rights crucial to mercantile societies. ${ }^{38}$

For Calvin too conscience in its morally depraved state had to be guided directly by God's love and grace. Calvin conceived of the liberty of conscience as a 'first and most essential right'. ${ }^{39}$ Jennifer Herdt explains how for Calvin natural law was 'linked emphatically with judicial conscience, and in particular with awareness of divine judgement. ${ }^{40}$ Conscience creates a state of continuous self-judgement as it 'brings [humans] before the judgement seat of God.' This judicial conception of conscience is entirely internal: the human individual's free conscience applies natural law in accordance with God's judgement. ${ }^{41}$ In other words, the Protestant Reformations impacted the relation between conscience and natural reason and natural law. Not the Church official but individual conscience - being where God resides in and speaks to humans - knows, interprets and applies natural law. Calvin had a keen eye for how humans often 'blind' themselves to 'the deliverances of conscience. ${ }^{42}$

Luther's antagonist, Desiderius Erasmus (c. 1469-1536) was a Renaissance humanist who advocated religious toleration. He was educated in the 'devotio moderna' and lived as an Augustianian monk for a short period of time before he became a freely travelling scholar and European citizen. Erasmus (as well-known, later greatly admired by Hugo Grotius) became known for his anticlericalism, egalitarianism, social reformism, and his attack on ecclesiastical corruption - for which he in turn came under attack of the Roman Catholic Church. His writings, as much of the Northern-Humanist's work, centered around the human conscience in general and the conscience of political leaders in particular.

Here it may be helpful to bring to mind Erasmus' admiration for Seneca's moral integrity and the 'holiness of Seneca's teachings.' ${ }^{43}$ Apart from the bible and Patristic literature, Erasmus drew on Seneca, other Stoics and Ancient philosophers, for his philosophia Christi, which entailed 'the restoration of human nature originally well formed'. ${ }^{44}$ Such 'rebirth' required moral instruction and a nurturing of 'the love of what is good' innate in humans. To that end, Erasmus - following the Stoics - prescribed the practice of 'daily self-examination' 45 a practice to tell the truth to oneself about oneself to gain self-knowledge and self-mastery.

\footnotetext{
${ }^{36}$ Luther, The Bondage of the Will, p 107-109

37 JE Nijman, 'Grotius' Imago Dei Anthropology: Grounding lus Naturae et Gentium', in International law and Religion, edited by Martti Koskenniemi, Monica García-Salmones, and Paolo Amoroso (OUP, 2017), pp. 87-110.

${ }^{38}$ Berman (n 6) 30

39 John Witte Jr, The Reformation of Rights: Law, Religion, and Human Rights in Early Modern Calvinism (CUP 2007) 2, 45-7; Witte also shows how therewith Calvin laid the foundation for the development of fundamental rights and freedoms.

40 Jennifer A. Herdt, Calvin's legacy for contemporary Reformed natural law, Scottish Journal of Theology 67(4):

414-435 (2014) at 419. Cf Berman I (n 6) 529-30 for Aquinas' theology of judgement.

${ }^{41}$ Herdt (40) 420.

42 Herdt (40) 417.

${ }^{43}$ Margo Todd, Christian Humanism and the Puritan Social Order (2002), 27-8

${ }^{44}$ Ibidem 29

45 Ibidem 31
} 
Erasmus' conception of conscience is less Thomist and more Stoic in nature. He undercut the power of the pastorate in the 'court of confession' with emphasis on the discipline of selfexamination without too much involvement of clerical intermediaries between the individual and God. Examination of the self, by the self could overcome sinful, vicious thoughts and inclinations and liberate right reasoning, that is, reasoning directed at the realisation of the common good. The latter, incidentally, was also a precondition for Erasmus' 'consensual model of lawful government'. ${ }^{46}$

Rather than a courtroom, Erasmus' conception of human conscience thus reflects a classroom - to stay with spatial metafors. It was first and foremost a space of learning for life on earth, receptacle of moral instruction set to bring about social reform through moral (self-)reform.

\subsection{Grotius' turn inwards: the concept of the free human conscience and forum conscientiae guided by caritas}

The Council of Trent (1545-1563), the Peace of Augsburg (1555), the Edict of Nantes (1598), are moments in the history of the Protestant Reformations and Counter-Reformation that testify to the controveries around the liberty of conscience. It was also one of the conceptual and theological drivers of the Dutch Revolt against the Netherlands' Spanish sovereign. The revolting provinces laid down the principle of freedom of conscience in the Union of Utrecht (1579) and then in 1581 in the Act of Abjuration with which they liberated themselves from the allegiances to their sovereign, Philips II. ${ }^{47}$

Hugo Grotius (1583-1645), while actively engaged with the legal affairs in and of the Dutch Republic, was also a dedicated theologian. The free conscience was central to Grotius' theological, political and legal thought and to much of his writings on peace and toleration both as a practitioner and a scholar. ${ }^{48}$

Grotius can count as an epitome of the focus away from the outside clerical authority onto the individual conscience itself as interpreter of the (natural) law to be applied by the human forum conscientiae that is pointed to in previous sections. Grotius liberated human conscience and thus human agency from the jurisdiction of the Roman Catholic Church. A political move of the highest importance for a Protestant member of the governing elite of the revolting Republic. Grotius thus secured a solid basis for ius gentium et naturae governing immediately the free conscience of sovereigns.

In Enlightenment Contested, Jonatan Israel explains, how in the second half of the seventeenth century, Holland was 'identified as a prime sourc[e] of denial of God, flagrantly

\footnotetext{
${ }^{46}$ Jardine (Ed) Erasmus' The Education of a Christian Prince, at vii

${ }^{47}$ An English translation of the text of the Union of Utrecht is in E.H. Kossman and A.F. Mellink, eds., Texts concerning the Revolt of the Netherlands (Cambridge: Cambridge University Press, 1974), pp. 165-73; article 13 states: 'each person shall remain free, especially in his religion, and that no one shall be persecuted or investigated because of their religion.'

${ }^{48}$ Grotius' draft Amsterdam Jodenreglement testify to the individual freedom of conscience, yet also to the limits on the exercise of public worship of non-Christian faiths. See Marc de Wilde (2017) 'Offering Hospitality to Strangers: Hugo Grotius's Draft Regulations for the Jews', 85(3-4) Tijdschrift voor Rechtsgeschiedenis (2017) 391433.
} 
defying consensus gentium'. ${ }^{49}$ Israel points to an 'organized movement' of 'atheism' at German universities led by Matthias Knutzen.

"He named his "sect" the Gewissener [Conscientiaries] because, he said, there exists no other true God, Religion, or Magistracy than Man's Conscience, the medium by which all men are taught "the three precepts of justice", as Bayle puts it, precisely recording Knutzen's formula as given in his tracts: 'to do no injury to anyone, to live honestly and give everyone his due". 50

More than Knutzen's formula, this formula was of course central to natural law theorists, including Grotius and Leibniz, ${ }^{51}$ ever since discussed by Roman Lawyer Cicero in De Officiis. Earlier in the seventeenth-century, Grotius had been accussed of deism and Socinianism and his famous etiami daremus disclaimer in DJBP had added to the controversies, while it actually seemed to have meant to provide stable ground underlying all theological differences: the universality of a free conscience as inner judge. Neo-stoic philosopher and Erasmian humanist, Justus Lipsius (Joost Lips) (1547-1606), whom Grotius admired, wrote for example in his 1598 Politica:

'even where there is no religion or fear of the Divine at all, there is still a tiny sprig of conscience, in danger, so to speak, from the bad soil. Conscience, then, is THE SMALL SPARK OR RIGHT REASON LEFT IN MAN, THE JUDGE AND INDICATOR OF GOOD AND EVIL DEEDS.'52

In Adamus Exul (1601), a biblical drama he personally send to Lipsius, ${ }^{53}$ Grotius examines the human conscience of Adam and Eve - and therewith of all humanity - before and after the Fall from Grace. The Thomist distinction between the abstract principles of natural law (synderesis) and their application by conscience (conscientia) shines through when the Angle speaks to Adam. ${ }^{54} \mathrm{~A}$ little later, God is speaking how he resides 'within [Eve's] kindling conscience. ${ }^{55}$

In Meletius (1611), the human conscience features within an irenistic argument aimed at bringing peace in church and state, in the Republic and beyond. ${ }^{56}$ The argument has often been summed up as 'Necessariis Unitas, in Non Necessariis Libertas, in Utrisque Caritas' ('unity in necessary things; liberty in uncertain things; charity in all things'). ${ }^{57}$ It was the same argument of freedom of conscience and minimalist Christian creed that carried De Veritate (1622/47).

\footnotetext{
49 J.I. Israel, Enlightenment Contested (OUP 2008) 166

50 Israel (n 48) 166

${ }^{51}$ GW Leibniz 'Codex luris Gentium' in P Riley (Ed) Leibniz Political Writings (Cambridge: CUP, 2 ${ }^{\text {nd }}$ ed 1988) 171-3.

52 Justus Lipsius, Politica: Six Books of Politics Or Political Instruction transl. Jan Waszink (Van Gorcum, 2004) Book

I, Ch 5, p 277. Lipsius provided many citations from the classics on conscience, such as Stobaeus' 'a good conscience is always free from fear', Cicero's 'nothing is more blissful than tranquillity of conscience', and Seneca's 'a bad conscience [...] is distressed and restless even in solitude.' The latter's more juristic language is there with 'Miserable you are, if you ignore this witness!' Whether Grotius drew on these requires more research. (Caps in original.)

${ }^{53}$ H. Nellen, Hugo Grotius: A lifelong Struggle for Peace in Church and State, 1583-1645 (Brill, 2014) 58.

${ }^{54}$ Grotius, Hugo. Adamus Exul. In The Celestial Cycle, edited by Watson Kirkconnell (Toronto: University of

Toronto Press, 1952) 16: 'Behold | Thy gifts of conscience, reason, active power | Of self-producing, selfcombining all | Innate ideas of intellectual truth, | Intelligible abstract principles, | Illimitably applicable.'

55 Ibidem 50.

${ }^{56}$ H Grotius, Meletius, ed and transl by GHM Postumus Meyjes (Brill 1988), 10.47-50; 28.113-15.

${ }^{57}$ Cf Meletius 91.
} 
Distinguishing between theoretical (doctrines (decreta) or principles) and practical (ethical precepts (praecepta) or rules), ${ }^{58}$ Grotius underscored the importance of the latter, i.e ethics and political philosophy in Meletius. This was also where his interest lied: how to live one's life well and how to develop a good social order? ${ }^{59}$ Created in imagine Dei, human is capable of doing 'good' and capable of making 'an effort' to improve after God's likeness and living by 'mutual love and friendship'. ${ }^{60}$ She is sufficiently uncorrupted to know natural law and apply it, yet corrupted by vice to a degree that conscience may err. ${ }^{61}$ This should however not lead to too harsh a verdict on humans. ${ }^{62}$ Humans can learn and return to virtue and virtuous judgement. ${ }^{63}$

The work human conscience does in Meletius is fourfold. First, it testifies empirically (ex post) to human's innate moral knowledge (natural law) and to human's free choice as it may act on this knowledge or err (consciously or unconsciously). It testifies to humans as free moral agents, who may then freely subject to law and authority. ${ }^{64}$ 'The repeated warnings of each individual conscience' when erred point to human moral depravity - with the Fall, 'nature became no longer "mother" but "stepmother"' - as well as to human 'answerab[ility]' for ethical failures.

Second, human conscience thus features as human's internal self-judge that applies the standards of natural law and justice to the self. It 'accuses us more or less severely according to the magnitude of our sins. ${ }^{65} \mathrm{~A}$ bad conscience thus also functions as internal judge and executor of punishment for the self. These self-accusations become harder to live with when the sins become heavier. Grotius refered a few times to the Stoic philosopher of self-control and self-mastery, Seneca, on whom Erasmus also drew. 'One of the frailties of the human condition is the obfuscation of the mind, which gives rise not only to inevitable error but even to an attachment to errors. ${ }^{66}$ Therefore Seneca propagated rigorous self-examination of the human conscience and self-education. After all, as Grotius cites Seneca again, '[i]f we want to be just judges of everything, we would first convince ourselves that none of us is without guilt.' ${ }^{67}$ Self-examination had to assist people in taking up 'responsib[ility] for their deeds' and stimulate virtues such as modesty. ${ }^{68}$

Third, conscience plays an important role in Grotius' theory of ethics. It provides ground for four categories of 'duties of love': towards i) God (eg prayer), ii) humanity (eg duty of friendship or charity 'on the ground of natural kinship in the image of God'), iii) society or the state (eg to be 'good citizens' and to subject to governmental authority), and iv) oneself (eg 'to preserve as best as he can his own life, safety and health' and thus not to 'commit suicide'). ${ }^{69}$ As the bottom-line, Grotius understood 'that brief and famous rule, highly

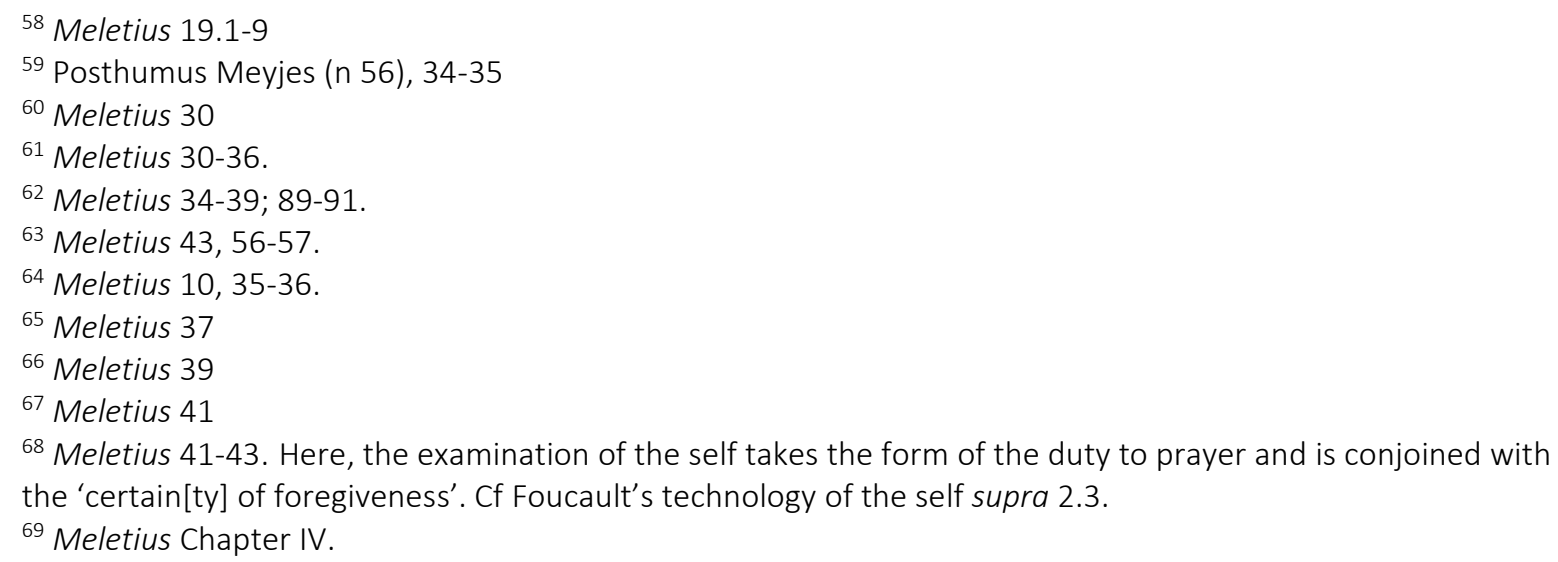


recommended by the emperor Hadrian: "Do not do unto someone else what you do not want done to yourself." 70 Grotius harped on the natural duty of all humans to care for their neighbour (caritas) and take her interests into account. ${ }^{71}$ Throughout Meletius, Grotius' Christian-humanist conception of human conscience conjoins 'knowing' and 'caring'. Human conscience is the best councillor or justice, it applies natural law and justice to specific cases and this includes the duties of love (duties required by assignative justice).

Finally, conscience enables humanity to agree, to consensus gentium: 'ethical precepts are mostly plainer and less complicated, it stands to reason that most people readily agree on precepts. ${ }^{72}$ Practical reason and virtuous judgment prevail over theoretical doctrines. Grotius' theory of natural religion and free conscience blends perfectly with his theory of natural law.

\subsection{The human conscience in Grotius' thought on ius gentium et naturae}

Grotius was well aware of the 'court of conscience' tradition of the Church of Rome, the handbooks of its moral theologians (Vitoria and Suarez) and the 'cases of conscience'. ${ }^{73}$ An Arminian Protestant, he broke with the confessional court version of the 'court of conscience' and reconceived conscientia as itself the internal judge and punisher of the self (these reponsibilities were not executed by the confessor). Grotius thus disentangled universal natural law - ius gentium et naturae - from the spiritual jurisdiction of the Roman Catholic Church. If human conscience errs, punishment consists in internal turmoil over the violations of one's obligations. In the internal court, natural law and justice, that is, expletive (strict) and attributive (distributive) justice, applied. ${ }^{74}$ As such, the human conscience came to underpin an international order in which ius gentium et naturae was backed up by punishment - and thus, true law - and in which both strict justice (perfect rights and duties) and distributive justice (duties of love) applied. The latter requires virtuous or 'well-tempered judgment' of all sovereigns. ${ }^{75}$

\section{A. Mare Liberum}

In Mare Liberum, conscientia features as a court. Grotius appealed directly to the 'upright conscience and fidelity' of 'the Rulers and Free Nations of the Christian World'. ${ }^{76}$ Right at the beginning Grotius makes clear what is at stake: who determines right and wrong? The rich and powerful would suggest, Grotius argues, 'that justice and injustice are distinguished [...] merely by the opinion and custom of mankind. ${ }^{77}$ This is 'absurd and unnatural' to Grotius. Clearly it would put the normative standard too low. Law is more than social facts, it is more than what in DJBP Grotius called 'might makes right'. ${ }^{78}$ If it is however not the rich and the

\footnotetext{
70 Meletius 68.

${ }^{71}$ Meletius 82, 77-87.

72 Meletius 89.

${ }^{73}$ See eg Mare Liberum chapter 13 and DIBP Prolegomena 36, where he shows to be well aware of the subjects matters discussed: promises, oaths, reprisals, warfare and so on. Also, Grotius refers to the 'courts of conscience' in Book II Ch X: 'internum animi tribunal'.

${ }^{74}$ Grotius (n 84) Book I.I.VIII, at 36.

${ }^{75}$ Grotius (n 84) Prolegomena 9.

${ }^{76}$ R Feenstra (ed and annotated) Hugo Grotius. Mare Liberum 1609-2009 (Brill 2009) 5.

77 Mare Liberum (n 74) 5

78 Grotius (n 84) Prolegomena 3.
} 
powerful who determine what law and justice entails, who does? What is the independent source of law and authority? Grotius builds his argument through the theological language of God as father of the 'one [human] race', one humanity with laws 'written in the minds and on the hearts of every individual, where even the unwilling and the refractory must read them'. ${ }^{79}$ Natural law is known to humans and conscience testifies to this knowledge and applies it.

Grotius repeated later in his 'Defence of Chapter V of Mare Liberum': the human conscience 'bear[s] witness to' the law of nations written in the Kings' hearts. ${ }^{80}$ Without a doubt, Grotius argued, ius gentium et naturae then is binding upon Kings like decrees are binding upon 'the common people'. ${ }^{81}$ So, when Grotius asked rhetorically what Christian Kings and Nations ought to think and do, he presented the principles of natural law as 'necessary to uphold the social structure of the whole human race and to maintain harmony thereof'. ${ }^{82}$ How then was this natural law of nations enforced? God, 'the king of the universe', would give 'the final punishment' yet until then:

'he delegates to intervene in human affairs two judges whom the luckiest of sinners does not escape, namely, every man's own conscience and his fame (or other men's estimation). These two tribunals are open to those who are barred from all others; to these the powerless appeal; in them are defeated those who are wont to win by might [...]. ${ }^{83}$

Conscientia as court and judge then is equivalent to what King or magistrate are to their subjects: judge and law enforcer. For Kings upon whom ius gentium et naturae is binding, the human conscience fulfills the judiciary function, the forum internum, where forum externum is absent. Conscientia is the inescapable tribunal of sovereigns, the seat of judgement that stands open to those to whom other tribunals are barred. And so, Grotius brought the natural law claim of the free sea against the Portuguese, not to the clergy and the moral theologians of the Church of Rome, ${ }^{84}$ but to court of conscience with which every Christian king, Catholic or Protestant, bestowed. These fora interna were to interpret and apply the principles of natural law to the case at hand and prove the claim right.

It is important to mention here that Mare Liberum was originally written as a chapter of De Iure Praedae, an extensive opinion on the seizure of the Santa Catarina together with an extravagant prize by the VOC. Some of the shareholders had a 'crise de conscience' over the affair, but as Martine van Ittersum points out Grotius did not side with them, yet with the VOC. ${ }^{85}$

\section{B. De jure belli ac pacis (DJBP)}

\footnotetext{
${ }^{79}$ Mare Liberum (n 74) 8-9 CHECK

80 Mare Liberum (n 74) ch 13

${ }^{81}$ Mare Liberum (n 74) 9

82 Ibidem 11

83 Ibidem 13.

${ }^{84}$ Ibidem opening of Ch 12 - Grotius refered to them and the fact that their 'reasons' cannot 'pacify the concience'.

${ }^{85}$ See on the 'Fruin Thesis', which speculates about the 'pangs of conscience' of VOC shareholders, M van Ittersum, Profit and Principle: Hugo Grotius, Natural Rights Theories and the Rise of Dutch Power in the East Indies 1595-1615 (Brill 2006) Chapter 3, at 113. See also the chapter of Roland Boer in this volume.
} 
The dedication of DJBP also addresses explictly the free conscience of the respective sovereigns of Europe. In DJBP, Grotius argues that the natural law of nations exists and is binding upon sovereigns and nations. Engaging with natural law and justice in their conscience would tell these sovereigns that much of the warfare they were involved in was in violation of this body of norms. In DJBP, the free human conscience provides ground to three important political moves.

First, the concept of human conscience enabled Grotius to establish a universal natural law applicable upon disputes within Christianity and between Christian and non-Christian peoples and sovereigns. Second, the free human conscience provided ius gentium et naturae with a decentralised system of law interpretation, application and enforcement in the forum internum. Crucial for his answer to contemporary scepticism about natural law and justice as applicable to sovereigns' and their nations. Third, the judge in the court of conscience was to apply natural law springing from both commutative and distributive justice. The latter was thus kept within the ius gentium et naturae.

As to the first point, Grotius articulated a rationalist take on natural law: human 'has [...] been endowed with the faculty of knowing and of acting in accordance with general principles [of natural law]. ${ }^{86}$ The human faculties of reason, free will and sociability (appetitus societatis), ${ }^{87}$ ensure natural law is knowable and applicable to a situation at hand. Human nature itself then is the source of ius gentium et naturae - 'the source of law properly so called.' ${ }^{88}$ Human intelligence and sociability enable humans to exercise 'well-tempered judgment'. This exercise of judgement, that is the application of ius gentium et naturae, then takes place in foro interno and may lead to right action. ${ }^{89}$

In DJBP Book I.I., Grotius famously continues 'The law of nature is a dictate of right reason' and he refers to Philo and Chrysostom to foreground reason and conscience. ${ }^{90}$ It goes to show how natural law is not dependent on revealed religion and law (ie divine law) yet universably knowable by and binding upon every human individual: 'When Gentiles that have not the [divine] law do by nature [...] the things of the law, these, not having the law, are the law unto themselves, in that they show the work of the law written in their hearts, their conscience bearing witness therewith, and their thoughts one with another accusing or else excusing them. ${ }^{\prime 91}$ Or, from Chrysostom: 'In place of the law conscience and the use of reason suffice.' 92 In other words, ius gentium et naturae is known by every ruler and can be applied directly and freely in her forum conscientiae. Here too conscientia bears witness to the existence of (universal) natural law binding upon sovereigns of all peoples.

As to the second point, having the sources of ius gentium et naturae in place, Grotius came to address another sceptic argument: that is, law is only law if it is effective and backed-up by

\footnotetext{
${ }^{86}$ De Jure Belli ac Pacis, Prolegomena para. 7. Hugo Grotius, De Jure Belli ac Pacis Libri Tres (1646 edition), The Classics of International Law, edited by James Brown Scott, translated by Francis Kelsey (Oxford: Oxford Clarendon Press, 1925), p. 13. Hereinafter DJBP.

87 Grotius (n 84) Prolegomena 6.

${ }^{88}$ Grotius ( $\mathrm{n} 84$ ) Prolegomena 8 (fn omitted).

${ }^{89}$ Grotius (n 84) Prolegomena 9.

${ }^{90}$ Grotius (n 84) Book I Ch 1.10, p 38.

${ }^{91}$ Grotius (n 84) Book I Ch 1.16, p 47.

92 ibidem
} 
force. In Prolegomena 19-20, Grotius argues that law is also law without an external court system to impose sanctions:

'Nevertheless law, even though without a sanction, is not entirely void of effect. For justice brings peace of conscience [conscientia], while injustice causes torments and anguish, such as Plato describes, in the breast of tyrants. Justice is approved, and injustice condemned, by the common agreement of good men. But, most important of all, in God injustice finds an enemy, justice a protector. He reserves His judgements for the life after this, yet in such a way that He often causes their effects to become manifest even in this life, as history teaches by numerous examples. ${ }^{193}$

Here as in Mare Liberum, conscientia fulfils the court function and punishes the self. Violation of natural law and justice was explicitly linked to the punishment of a tormenting conscience terrorising the self. In other words, in the absence of an external court system such as in a domestic legal order, ius gentium et naturae had in fact a forum internum to rely on. It was backed-up by a decentralised network of 'courts of conscience' capable of punishment. We find references to the punishment of a bad conscience tormenting the sovereign who violates ius gentium et naturae at a number of places.

At the end of the final chapter of DJBP Book III, we find a variation of what Grotius wrote in the Dedication of Mare Liberum on the two tribunals for sovereigns: 'the duty of kings to cherish good faith scrupulously, first for conscience's sake and then also for the sake of the reputation by which the authority of the royal power is supported. ${ }^{94}$ Also in the previous quote from Book I.I.16, the human conscience features as the internal judge who accuses and excuses the self of violating natural law. ${ }^{95}$

While the law that is to be applied by conscientia is universal, Grotius expects more from the individual free conscience that maintains an immediate relationship with God. ${ }^{96}$ In Book III ch xxv, Grotius indicates that without faith the human conscience derails (more easily) and sovereigns become 'like wild beasts.' For 'the sake of [a well-functioning] Conscience' (conscientia) and a good reputation, 'on which depends the Authority of their Government', the Sovereign's practice of faith is crucial. Moreover, a 'quiet [as in good] Conscience' when in war can only exist 'unless we aim at Peace in every Thing we do throughout the whole Course of war. ${ }^{97}$ An immediate conversation with God in prayer, facilitates the sovereign soul to scrutinise itself in anticipation of God's judgement and thus facilitates well-tempered - peaceoriented - judgement in this life.

Grotius conceived of conscientia also as a corrective authority when there is unclarity about law and justice in a strict sense. ${ }^{98}$ Judgement gives also direction to human action ex ante. If this guidance is taken lightly or ignored humans 'degenerate and become brutish'. ${ }^{99}$ The human conscience thus functions to ensure natural law and justice - including both strict and distributive justice - find implementation and application in relations among sovereigns.

\footnotetext{
93 Grotius (n 84) Prolegomena 20

${ }^{94}$ Grotius (n 84) Book III.xxv.i. at 860-61.

${ }^{95}$ Supra $\mathrm{n} 89$.

96 'Conscience itself, which, properly speaking, is under the Dominion of God only.' DJBP Book I Ch II. 7.2, ed 1632, Liberty translation, $\mathrm{p}$ 200; the explicit mentioning of conscience is absent in the Kelsey translation. See also Book III.

97 Grotius (n 96) 1639.

98 In Book II, Ch XXIII.II on the 'Dubious causes of war': 'Nihil faciendum contra animi dictamen quamvis errans.' Hugo de Groot, De iure belli ac pacis, B.J.A. de Kanter-van Hettinga Tromp (Ed), (Brill 1939) 566.

99 Grotius (n 96) 1116.
} 
Distributive justice or virtue - such as moderation - should assist in the application of strict justice. For example, earlier in Book III.II, one of the chapters on 'moderation', that is, the chapter on 'moderation concerning the Right of killing Men in a just War', section 2 discusses 'Who may be killed with a safe Conscience.' ${ }^{100}$ Here, moderation is explicated (like any virtue) to be a requirement of iustitia interna. First Grotius refers back to Book I.I. in which he distinguished 'Justice strictly taken' from wider Justice, which springs from Charity. In the forum internum, which is the judge that applies iustitia interna, killing is justified when the victim was 'culpable' in 'so heinous a Manner' that death is proportionate. ${ }^{101}$ External judgement, or the application of strict law and justice, requires guidance by virtue and distributive justice. Conscience has to assure external judgement is applied with moderation and care. ${ }^{102}$

This brings me to the third point. As the above shows, in order to have 'peace of conscience', sovereigns have to apply the law springing from both expletive and distributive justice, that is, abide by both perfect and imperfect duties. Grotius keeps the latter - the duties constituted by distributive justice - within the ius gentium et naturae system by a conception of the human conscience as a court monitoring obedience of the self. Thereby, what he called in Meletius the 'duties of love' are supported by court system too. Here, Grotius may perhaps draw on Erasmian thinking about conscience as a space for learning and caring for the self and the good of society. The good of society has to be kept in mind, as again DIBP Book III, chapter xxv articulates, for justice to be done. ${ }^{103}$ Also, when strict justice is enforced it should be guided by attributive justice to assure proportionate punishment. ${ }^{104}$ Caring for the self - as social being - is caring for others and for the good of society: from human nature spring the duty to obey natural law and justice: 'deny[ing]' the fundamental principle of natural law would entail 'doing violence to [one]self.' ${ }^{105}$ Conscience is where this is enforced, where humans interpret and apply the law and make decisions. It demands human to apply it virtuously that is while respecting others and taking their interests into account.

To sum up. In both Mare Liberum and De Jure belli ac pacis, the human conscience bears witness to the existence of ius gentium et naturae. It provides ground for a decentralised court system, alternative to the confessional court system and filling the gap of the nonexistent external courts for sovereign and nations.

For Grotius moreover the stakes were high: sceptics argued law without a system of enforcement could not be law. Once liberated from the jurisdiction of the Roman Catholic Church, ius gentium et naturae needed to be backed up by another court system. Grotius proceeded with the 'court of conscience' to provide ius gentium et naturae with an alternative judge and punisher. With an alternative system in place, modern ius gentium et naturae was undisputably binding on its subjects. This internal judge was bound to apply strict ànd distributive justice.

\footnotetext{
100 Grotius (n 96) 1422

101 Grotius (n 96) 1422, 1481. See also, DJBP Book III.X, sections 2-3; Book III.XIV; Book III.XVI.

${ }^{102} \mathrm{Cf}$ Koskenniemi on the internal and external obligations binding in conscience, M Koskenniemi 'Imagining the Rule of Law: Rereading the Grotian "Tradition", 30 (1) EJIL 2019, 30-31.

${ }^{103}$ DJBP Book III.XXV

104 DJBP Book II.XX.40 on Punishments, for example, the notion of excessiveness or disproportionate plays a crucial role.

105 Grotius (n 84) Prolegomena 39.
} 


\section{CONCLUDING}

In the Age of Conscience, 'modern' ius gentium et naturae emerged. This chapter has examined how various early modern conceptions of conscientia related to this emergence of ius gentium et naturae. The Thomist conception of conscience as an internal court or judge was central to the work of Vitoria and instrumental to his development of ius gentium et naturae to provide 'safety of conscience' to the Spanish Court. In Grotius' work, the judicial function of conscientia was mobilised to support his argument that ius gentium et naturae was true and universal law - law backed-up by a court system albeit a somewhat alternative one. Conscientia underpinned moreover a ius gentium et naturae that consisted in more than strict law and justice and in more than perfect rights and duties. Disregarding imperfect duties or distributive justice would be punished by the forum internum too. Grotius argued that any European sovereign was obliged to apply and implement perfect rights and duties in conjunction with broader law and justice and the imperfect rights and duties that sprang from it. Moreover, without the free conscience legal institutions as oath and promise could not play their foundational role in law, and justice could not be done.

Unfortunately, Foucault never turned to the Protestant technologies of the self. Bringing Foucault's research question - 'How have certain kinds of interdictions required the price of certain kinds of knowledge about oneself?' 106 - to Protestant international law thinkers and thought will make for great further research. Arguably, the rule of conscience "democratised" with the withdrawal of the Church as its ruler. Yet with the self-examination and guidance of conscience in an unmediated relation with God (in prayer) and without externally administered unburdening practices other power/knowledge production arose. Foucault's point that the classical 'technology of the self' as care for the self and therewith for others (including the polis) was lost in the Christian (Roman Catholic) tradition surely deserves research from an Erasmian humanist perspective.

The 'technology of the self' operational in Grotius work may be understood as predominantly Erasmian in nature. The practice of the internal judge requires self-examination against the standards of both strict and distributive justice - or: the duties of strict justice and those of love or caritas. Conscientia then is the space where humans exercise self-examination and thereby self-cultivation and self-mastery. Since human is a social being, the care for the self includes care for others and for the good of society. Conscience infuses mercy and caritas to direct human actions also in relations among sovereigns and states, both in peace and in war. This is the role of conscience that we find in Grotius'work. The often mentioned 'bad conscience' bears witness to how frequently, at the same time, humans err. Grotius' court of conscience is a space where knowledge is applied: where judgment is formed and cultivated. The idea of 'well-tempered judgement', that is, judgement guided by virtue - most importantly, moderation (temperantia) - when applying ius gentium et naturae, carries DJBP.

The early modern development in theological and legal thought that made every sovereign her own interpretative authority in the court of conscience was eminently suitable to the emerging European system of sovereign states and the ensuing 'horizontal' system of international law. Scholarly scrutiny of Grotius' peace-through-law project has pointed to the weakness of his conception of ius gentium et naturae. Conscientia as the court for sovereigns in international relations ... . Is that not very close to Hobbes' argument that there exists no

${ }^{106}$ Foucault (n 34) 16. 
international law as there is no external legislature and court? Who decides over the sovereign self and who judges her actions? Does this not lead exactly to the ideas of the $19^{\text {th }}$ century scholars who conceive of international law as merely Selbstverpflichtung?

In the course of the next centuries, conscientia (and surely its intermediate role in the relation with God) gradually faded into the background of international law and international legal thought; but it never disappeared completely. Obviously it featured prominently in Hobbes'107 and still in Vattel's work. ${ }^{108}$ It surfaced for example in the work of scholars like Oppenheim ${ }^{109}$ and Politis. ${ }^{110}$ Martti Koskenniemi has shown brilliantly how the 'Men of 1873' haughtily understood themselves as 'the legal conscience of the civilized world'. ${ }^{111}$ Today's international criminal law includes 'the conscience of humanity,' which can be 'deeply shock[ed]'. ${ }^{112}$ Similarly, it features in the Preamble of the Universal Declaration of Human Rights (1948): the 'outraged' conscience of humankind gave birth to the UDHR. Its first article has a long pedigree some of which we discussed above: 'All human beings are born free and equal in dignity and rights. They are endowed with reason and conscience and should act towards one another in a spirit of brotherhood $[\mathrm{sic}] .^{113}$

Generally, 'conscience' is assumed or alternatively used in international law completely uncritically as a natural place of morality and justice. With the human conscience explictly or implicitly carrying international law comes however a space for politics. As we have seen time and again, while it is the space for humans to apply moral knowledge it is also the space to err profoundly. While law presupposes its application by the human conscience, without the latter the former becomes unimaginable, the politics that comes with the interpretations of the court of conscience, like with any court, requires our scrutinizing attention.

\footnotetext{
107 Th Hobbes, Leviathan (1651), ed by R Tuck (CUP, Cambridge Texts in the History of Political Thought, 1991) Chapter 30 'The office of soveraign Representative', at 244: 'there being no Court of Naturall Justice, but in the conscience onely; where not Man, but God raigneth'.

108 E de Vattel, Le Droit Des Gens Ou Principes De Law Loi Naturelle [Law of Nations or the Principles of Natural Law] (Washington: Carnegie Institution of Washington, 1916) eg at 10a and 11a: 'external right do not destroy the obligation that the internal right imposes on the conscience of each individual' and 'the necessary Law of Nations, which is the inner law of conscience'.

109 L Oppenheim, 'The Science of International Law: Its Task and Method', 2 (2) American Journal of International Law (1908), 313-56, at 331

$110 \mathrm{~N}$ Politis, 'The Status of the Individual in International Law' in The New Aspects of International Law (1928) 1831, at 20: 'the legal conscience of nations'.

${ }^{111}$ M Koskenniemi, The Gentle Civiliser of Nations. The Rise and Fall of International Law 1870-1960 (Cambridge: CUP 2002) 41 et seq.

112 Rome Statute 1998, Preamble.

113 Universal Declaration of Human Rights, GA Res. 217 A, 10 December 1948.
} 